\title{
A Black Carbon Emission Data Base For Atmospheric Chemistry and Climate Studies
}

Jane Dignon, Harold E. Eddleman and Joyce E. Penner

Global Climate Research Division

October 1994

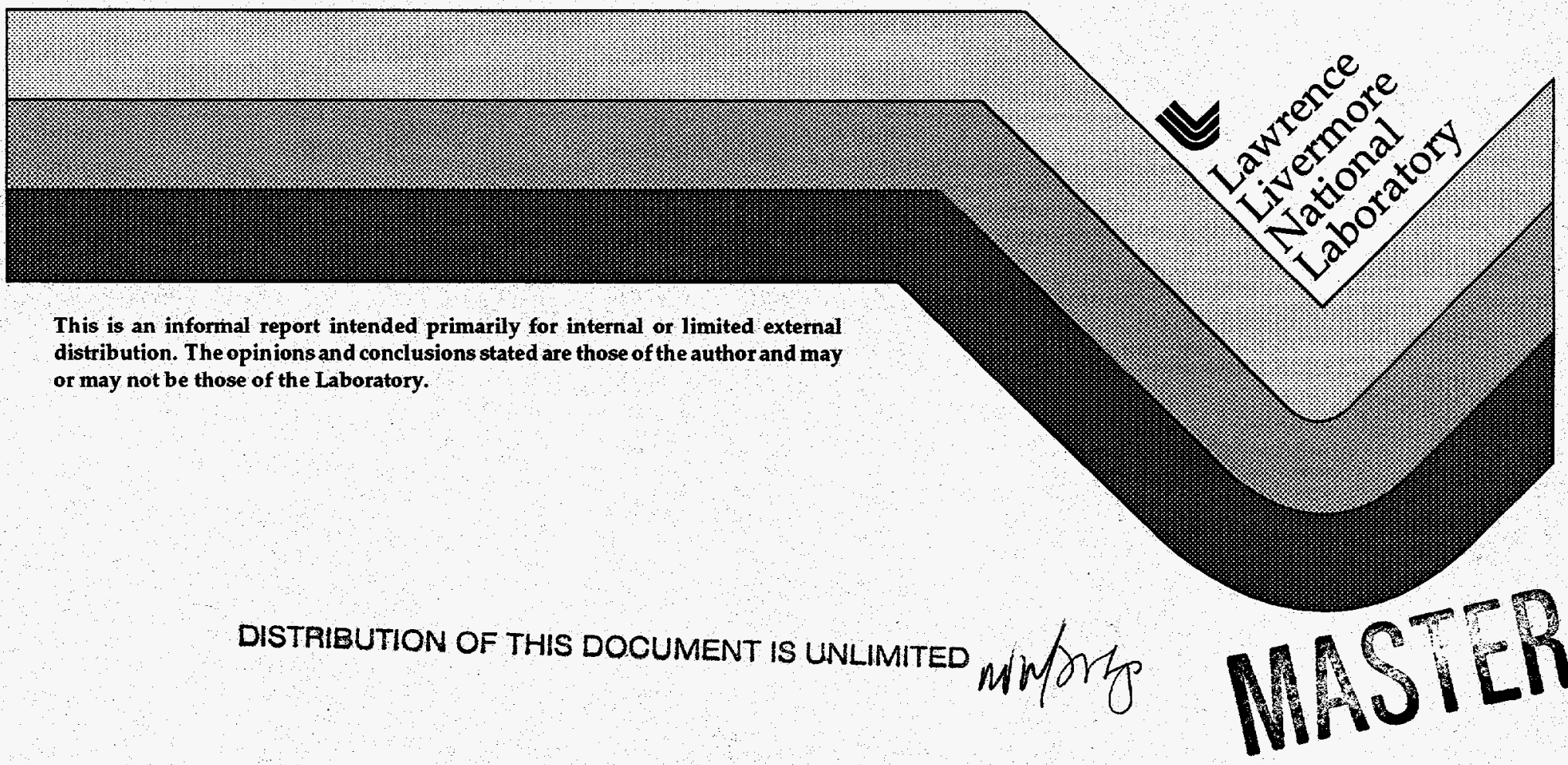




\section{DISCLAIMER}

This document was prepared as an account of work sponsored by an agency of the United States Government. Neither the United States Government nor the University of California nor any of their employees, makes any warranty, express or implied, or assumes any legal liability or responsibility for the accuracy, completeness, or usefulness of any information, apparatus, product, or process disclosed, or represents that its use would not infringe privately own rights. Reference herein to any specific commercial products, process, or service by trade name, trademark, manufacturer, or otherwise, does not necessarily constitute or imply its endorsement, recommendation, or favoring by the United States Government or the University of California. The views and opinions of authors expressed herein do not necessarily state or reflect those of the United States Government or the University of California, and shall not be used for advertising or product endorsement purposes.

This report has been reproduced directly from the best available copy.

Available to DOE and DOE contractors from the Office of Scientific and Technical Information

P.O. Box 62, Oak Ridge, IN 37831

Prices available from (615) 576-8401, FTS 626-8401

Available to the public from the National Technical Information Service

US. Department of Commerce

5285 Port Royal Rd.,

Springfield, VA 22161 


\section{DISCLAIMER}

Portions of this document may be illegible in electronic image products. Images are produced from the best available original document. 


\title{
A Black Carbon Emission Data Base for Atmospheric Chemistry and Climate Studies
}

\author{
Jane Dignon, Harold E. Eddleman and Joyce E. Penner \\ University of California \\ Lawrence Livermore National Laboratory
}

\section{Description}

A global data base of black carbon emissions to the atmosphere from fossil fuel combustion has been compiled for the use in atmospheric chemistry and climate studies. The resolution provided is at $1^{\circ}$ latitude by $1^{\circ}$ longitude based on previous work by Matthews (1983), Lerner et al. (1988), and Dignon (1992). A more extensive description of the assumptions made and emission factors used in this data base can be found in Penner et al. (1993). The original work of Penner et al. (1993) provides the emissions inventory data on a $5^{\circ}$ by $5^{\circ}$ resolution.

The units of emission for this updated version of the inventory yield a global total of $12.6 \mathrm{TgC} / \mathrm{y}$ and are given as the mass in metric tons of carbon for each $1^{\circ} \times 1^{\circ}$ grid. It is important to note that this is not equivalent to a flux, in that the area of the grid boxes vary latitudinally. The emissions are expected to represent the emissions for a typical mid-1980s year. The distribution of emission is based on national totals and then mapped on to the $1^{\circ} \times 1^{\circ}$ grid according to the updated population mapping of Logan (1993). A description of this mapping procedure can be found in Dignon (1988).

The grid for these data bases, $(\mathrm{i}, \mathrm{j})$ arrays, is $(360,180)$, which represents 1 degree (lon,lat) resolution. Here, $\mathrm{j}=1,180$ and $\mathrm{j}=1$ represents the latitude band 90 degrees south to 89 degrees, i.e. centered at 89.5 degrees south; $j=180$ represents the band from 89 degrees north to 90 degrees north, i.e. centered at 89.5 degrees north. Longitude is represented as $i=1,360$, where $i=1$ represents the band from 180 degrees (international date line) to 179 degrees west, i.e. centered at 179.5 degrees west; $i=360$ is the band from 179 
Figure. Data base array structure.

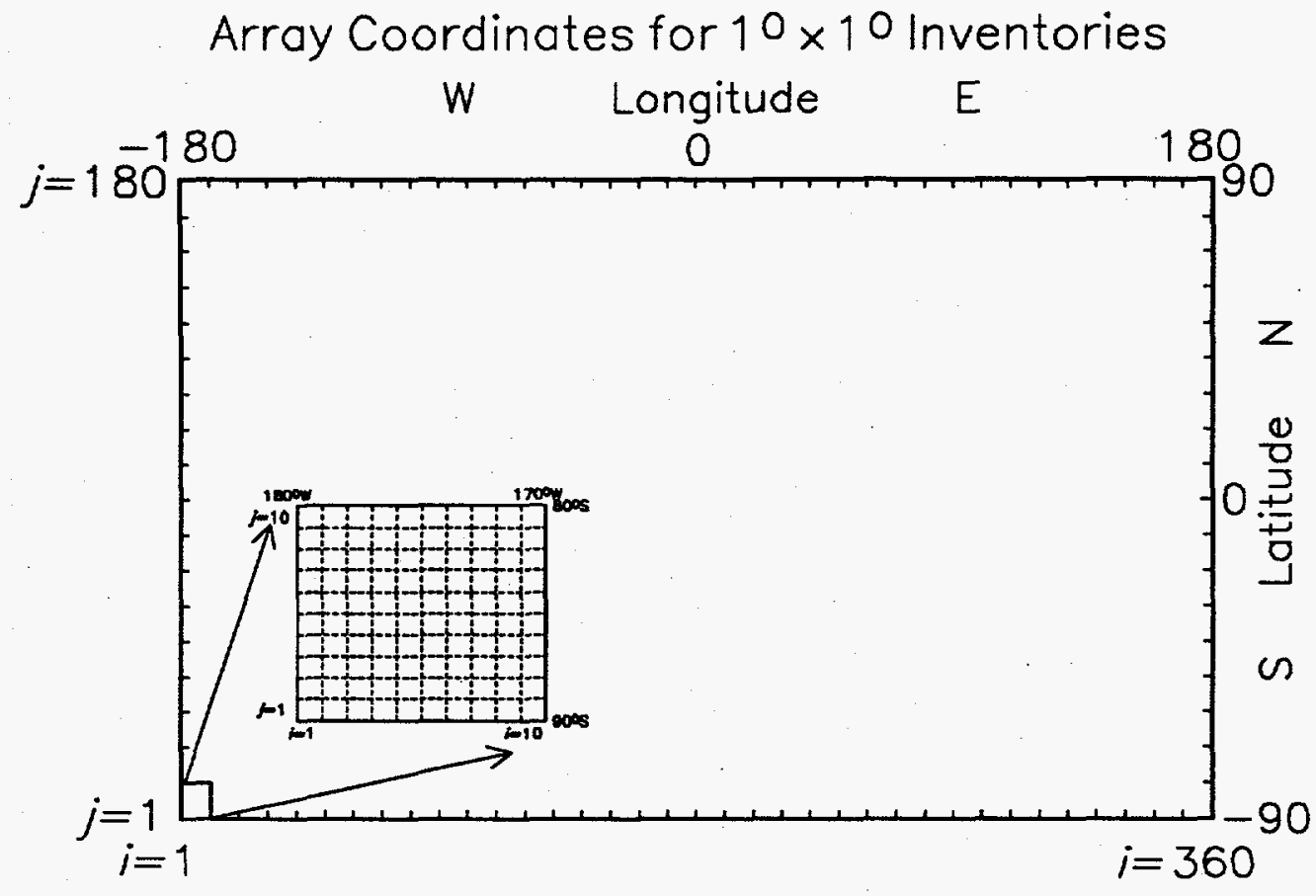

degrees east to 180 degrees (date line), i.e. centered at 179.5 degrees east. The accompanying Figure illustrates the structure of the arrays.

The appendix provides a sample FORTRAN code for reading the array. The data file is structured in the IGAC GEIA (International Global Atmospheric Chemistry Global Emissions Inventory Activity) standard format and is anticipated to be officially registered with that group in the near future.

Acknowledgements: Work performed under the auspices of the U.S. Department of Energy by the Lawrence Livermore National Laboratory under contract No. W-7405-Eng48. 


\section{References}

Dignon, J., 1988. Time and Spatially Dependent Estimates of Pollutant Trace Gas Emissions and their Effect on Tropospheric Ozone, Doctoral Dissertation, State University of New York at Stony Brook.

Dignon, J., 1992: $\mathrm{NO}_{x}$ and $\mathrm{SO}_{x}$ emissions from fossil fuels: A global distribution, Atmospheric Environment, 26A, 1157-1163.

Lerner, J, E., E. Matthews, and I. Fung 1988: Methane emission from animals: A global high resolution data base, Global Biogeochemical Cycles, 2, 139-156.

Logan, J.A., 1993: manuscript in preparation, for population.

Matthews, E., 1983: Global vegetation and land use: New high-resolution data bases for climate studies, Journal of Climate and Applied Meteorology, 22, 474-487.

Penner, J.E., H.E. Eddleman and T. Novakov, 1993: Towards the development of a global inventory of black carbon emissions, Atmospheric Environment, 27A, 1277-1295. 